for beginning students to prepare. This work was undertaken at my suggestion by some students who were in need of financial assistance in their laudable endeavor to obtain a college education. It was undertaken both for the purpose of affording some aid in this way, and also for the purpose of assisting teachers and schools, especially secondary and normal schools, in the supply of material which is often difficult to obtain.

It should perhaps be stated that neither I, nor the botanical department here, has any official connection with, nor financial interest in, the scheme. At the same time I have taken a lively interest in the work in order to be assured that the material and the preparations should be of the first order. The persons who make the preparations are thoroughly familiar with modern methods and have attained a high degree of skill in preparing them. The permanent slides showing sexual organs and sexual processes in plants of the different groups are excellent and very beautiful. I am quite sure that those who are familiar with good technique will be quite surprised at the high degree of excellence presented in these slides, and certainly they represent the structures in a strikingly accurate manner. They put up in addition to other material, a 'high school set.' Persons or schools desiring further information can obtain a price list by addressing 'The Ithaca Botanical Supply Co.,' Ithaca, N. Y.

Geo. F. Atkinson.

\section{DO FISHES REMEMBER?}

A RECENT paper* by Professor L. Edinger, entitled 'Haben die Fische ein Gedächtniss,' is primarily a statement of the conclusions which its author has reached as a result of his questionaire, 'Do Fishes Remember?' sent out in 1897. These conclusions are prefaced by some discussion of comparative psychology in general and some account of the sensepowers of fishes. The former is judicious but not new; the latter is convenient though not complete. Dr. Edinger is inclined to accept the decision that fishes do not hear sounds,

* Reprinted from Allgemeinen Zeitung,"Münohen, 21 und 23 October, 1899. though he seems not to know of the experiments of Dr. F. S. Lee, experiments more conclusive than any he reports.

Dr. Edinger's question as to memory is not about the existence of certain feelings of a thing as having been experienced before, but about the possibility of permanent associations, of after-effects of experiences. He asks concerning the fish nervous system, "Is this apparatus capable of in any way preserving impressions made upon it ; do there exist after-effects due to previous experiences?" p. 16. Or, in other words, "Can impressions which are new to the animal, gain an influence on its activities; especially can they preserve this influence for a considerable time?" p. 17. He decides in a rather half-hearted way that they can, on the basis of the evidence obtained from the answers to his questionaire and elsewhere. He summarizes this evidence as follows: "(1) The inborn impulse to flee can be lessened by the animal becoming accustomed to impressions which formerly frightened it, but this tameness is lost if new stimuli enter into the experience. The impulse to flee can also appear in the presence of stimuli which have never been present before. Animals become afraid. By habit the sight of the one who feeds them may take the place of the optical or chemical stimulus which ordinarily leads to the act of feeding" p. 28.

Dr. Edinger's limitation of fishes' powers of forming associations and being influenced by them more or less permanently, to the single cases of tameness, fear and associations between the feeder and feeding, is misleading. It is no characteristic of fishes' mentality to form such habits rather than others. The prominence of such in the answers to the questionaire is due, not to the mental constitution of the fish, but to the interests of the observers. As a matter of fact the questionaire proceeding seems a very awkward way of answering the question about the permanent effects of novel experiences. One can, as has been shown in the December number of the American Naturalist, get direct evidence of the fact and demonstrate it to a class in the space of five hours.

Although familiarity with animal psychology proper and a bit more ingenuity might have 
made Dr. Edinger's work more effective and his presentation much briefer, one cannot help feeling great satisfaction at seeing an eminent neurologist realize the value of comparative study by psychological as well as morphological methods. One must also admire the caution and thoroughness with which Dr. Edinger examines animal behavior. Above all one rejoices to see a piece of work in comparative psychology which presents facts without quarreling over the meanings of words.

Teachers College,

$$
\text { Edward Thorndike. }
$$
Columbia University.

THE GERMAN CONSULAR SERVICE.

Mr. Richard Guenther, Consul General of the United States of Frankfurt, writes to the Department of State that the 'seniors' of the Merchants Association of Berlin have addressed a memorial to the Prussian Secretary of Commerce, and at the same time to the Chancellor of the German Empire, which appears to be in response to an inquiry from the Secretary of Commerce, and states what reforms in the German consular service are deemed necessary. The following is a synopsis of the somewhat lengthy document: The main duty of the consul should be to make careful and detailed reports concerning economic occurrences in his consular district. These reports should give not only the figures of the exports and imports, but should also deal with the development of the commerce and the home industries of the country. The consul should be able to point out these conditions upon his own initiative, as well as in response to inquiries from home. He should be well informed about commercial matters at home, as well as in touch with the business world of his district. Means should be at his disposal for travel and he should be compensated for services rendered. Knowledge of the language of the country, as well as of the leading languages of the world, should be of prime consideration. The promotion system of Great Britain should be followed, whereby consuls are transferred between countries where the same languages and similar economic conditions prevail, so that transfers of a consul from China to Russia and thence to Spanish America, for example, should be avoided. Reports concerning the commerce of the foreign country should give comparisons with previous years and be published at home in such a manner as to reach all interested. The letter says that these requirements are more or less realized in foreign countries. The consuls of the United States of America especially have rendered very useful services to the commerce and industries of their home country and have furnished proof that the establishment of commercial consulates bears rich fruit, in spite of the fact that a consul can hardly acquire such special knowledge of trade conditions in the several branches as an agent of some business house. The letter endeavors mainly to show the great desirability of substituting the large number of German 'Wahlkonsuln'-i. e., German merchants resident in some foreign country who act as consuls - by regularly paid consuls, who will give their whole time to their consular duties, and states that a reform is expected mainly from an increased and improved service in the regular consulates, recommending the appointment of commercial attachés to the important consulates, as has already been done at Chicago, Buenos Ayres and Constantinople. It is recommended that the qualifications for appointment as consuls should be of a more practical nature and not so much the mere knowledge of law. The letter also calls attention to the great usefulness of the Philadelphia Commercial Museum.

\section{EDUCATION IN THE UNITED STATES.}

The United States educational exhibit at the Paris Exposition will include a two-volume work entitled 'Education in the United States,' which has been planned and edited by Professor Nicholas Murray Butler of Columbia University.

The work consists of nineteen monographs, which, taken together, give a complete view of the present educational activity of the United States. It is proposed to present copies of the work to the leading governments, public libraries and educational institutions of the world, and the public will be given opportunity to purchase copies at a moderate price. 